\title{
NILAI POSITIF METODE STIMULUS - RESPON TERHADAP PEMBELAJARAN MATEMATIKA DI KELAS VI SD NEGERI 163086 TEBING TINGGI
}

\author{
Maimunah* \\ Surel : maimunahspd1902@gmail.com
}

\begin{abstract}
The design of the participant's action research was taken because researchers participated directly in the research process from the beginning to the end of the study. Doing the same activity in the first cycle until the formative test II turns out the results can be stated that students have succeeded. The results of research conducted by Saki (2002: 74) that the planned time allocation is only one meeting, it turns out in the implementation of the action to be three meetings but oriented learning on the Stimulus-Respondent Learning Approach can improve understanding of fast multiplication in class VI SD Negeri 163086 Tebing High School Year 2016/2017.
\end{abstract}

Keywords: Learning Approach, Stimulus-Response

\begin{abstract}
ABSTRAK
Rancangan penelitian tindakan partisipan ini diambil karena peneliti berpartisipasi langsung dalam proses penelitian mulai dari awal sampai berakhirnya penelitian. Melakukan aktivitas yang sama pada siklus I sampai dengan tes formatif II ternyata hasilnya dapat dinyatakan bahwa siswa sudah berhasil. Hasil penelitian yang dilakukan oleh Saki (2002: 74) bahwa alokasi waktu yang direncanakan hanya satu kali pertemuan, ternyata dalam pelaksanaan tindakan menjadi tiga kali pertemuan tetapi pembelajaran berorientasi pada Pendekatan Pembelajaran Stimulus-Respondapat meningkatkan pemahaman perkalian cepat pada siswa kelas VI SD Negeri 163086 Tebing Tinggi Tahun Pelajaran 2016/2017.
\end{abstract}

Kata Kunci: Pendekatan Pembelajaran, Stimulus-Respon

\section{PENDAHULUAN}

Sejalan dengan kurikulum SD, Kurikulum merumuskan tujuan pengajaran matematika di sekolah dasar yaitu siswa diharapkan mampu (1) melakukan operasi hitung penjumlahan, pengurangan, penjumlahan, pembagian, beserta operasi campurannya, termasuk yang melibatkan pecahan, (2) menentukan sifat dan unsur berbagai bangun datar dan bangun ruang sederhana, termasuk penggunaan sudut, keliling, luas, dan volume, (3) menentukan sifat simetri, kesebangunan, dan sistem koordinat, (4) menggunakan pengukuran: satuan, kesetaraan antar satuan, dan penaksiran pengukuran, (5) menentukan dan menafsirkan data sederhana seperti ukuran tertinggi, terendah, rata-rata, modus, serta mengumpulkan, dan menyajikannya, dan (6) memecahkan masalah, melakukan penalaran dan mengkomunikasikan gagasan secara matematika. (Depdiknas SD, 2001:9).

Sesuai dengan tujuan khusus pembelajaran dan tujuan pengajaran matematika di Sekolah Dasar (SD) di atas terlihat bahwa siswa diharapkan mampu dan terampil menggunakan bilangan dengan operasi hitung serta dapat 
menerapkannya dalam kehidupan seharihari

Berdasarkan hasil observasi dan dialog dengan seorang guru yang mengajar matematika di Kelas VI SD Negeri 163086 Tebing Tinggi Tahun Pelajaran 2016/2017. dapat diketahui bahwa dalam kegiatan pembelajaran perkalian dan pembagian secara cepat dan tepat untuk bilangan cacah : (1) guru mendemonstrasikan keterampilan melakukan operasi (berupa operasi yang melibatkan “+, -, x, : “) siswa hanya diberi kesempatan untuk bertanya jika ada hal-hal yang belum jelas, kemudian guru mengecek siswa yang belum mengerti dan menjelaskan kembali bahan ajar yang belum dipahami, (2) guru memberi contoh soal tentang pemakaian suatu operasi dan siswa diberi latihan soal, (3) guru memberikan tugas untuk mengakhiri kegiatan, (4) dalam mengajarkan konsep perkalian dan pembagian secara cepat dan tepat untuk bilangan cacah, guru hanya bersumber pada buku ajar tertentu sebagai satu-satunya sumber yang siap disajikan pada siswa, (5) guru belum secara serius menggunakan alat peraga untuk memanipulasi benda abstrak, sehingga siswa tidak terlibat aktif dalam proses pembelajaran, akibatnya siswa lebih cenderung bersikap pasif dalam belajar dan sekedar menghapal simbol-simbol bilangan cacah tanpa mencerna makna yang dipelajarinya. Kondisi belajar matematika dengan cara menghapal mengakibatkan pengetahuan yang diperoleh siswa cepat dilupakan dan tanpa meninggalkan bekas. As'ari (1998:2) menyatakan bahwa belajar matematika dengan menghapal dan menggunakan algoritma secara efektif merupakan pendekatan

Stimulus-Respon

(Behavioristik). Berdasarkan uraian di atas peneliti tertarik untuk melakukan penelitian mengenai pembelajaran berorientasi pada Pendekatan Pembelajaran Stimulus-Respon dalam upaya meningkatkan pemahaman konsep perkalian dan pembagian secara cepat dan tepat untuk bilangan cacah pada siswa .

\section{Batasan Masalah Dalam PTK}

Sesuai GBPP 2007, Pokok bahasan pembagian dan perkalian. Masalah yang diteliti berkaitan dengan 2 sub pokok bahasan dari 8 sub pokok bahasan bilangan cacah yaitu (1) perkalian sebagai perkalian berulang dan (2) pertukaran tempat terhadap operasi hitung. Pemilihan kedua sub pokok bahasan tersebut dengan alasan bahwa konsep paling mendasar pada pembagian adalah pembagian berulang.

Tujuan Penelitian Tindakan

Sejalan dengan masalah penelitian yang telah dirumuskan di atas, maka penelitian ini bertujuan untuk, mendeskripsikan langkah-langkah pembelajaran berorientasi pada Pendekatan Pembelajaran Stimulus-Respon yang dapat meningkatkan pemahaman siswa Kelas VI SD Negeri 163086 Tebing Tinggi Tahun Pelajaran 2016/2017. terhadap konsep perkalian dan pembagian secara cepat dan tepat untuk bilangan cacah .

Manfaat Penelitian Tindakan

Hasil penelitian ini diharapkan dapat memberikan manfaat terutama sebagai alternatif pembelajaran untuk meningkatkan pemahaman perkalian dan pembagian secara cepat dan tepat untuk bilangan cacah pada siswa Kelas VI SD Negeri 163086 Tebing Tinggi Tahun Pelajaran 2016/2017. 
1.Pembelajaran Berorientasi pada Pendekatan Pembelajaran Stimulus.

2. Meningkatkan Pemahaman.

Belajar dan Mengajar Matematika

Ada berbagai pendapat dan pengertian belajar. Gage (dalam Dahar, 1988:12) menyatakan bahwa belajar dapat didefinisikan sebagai suatu proses dimana suatu organisma berubah perilakunya sebagai akibat pengalaman. Selanjutnya Winkel (1991:36) menyatakan bahwa belajar adalah suatu proses mental yang berlangsung dalam interaksi aktif dengan lingkungan dan menghasilkan perubahan dalam pengetahuan dan pemahaman, keterampilan dan nilai sikap yang relatif konstan dan berbekas.

Seseorang yang melakukan aktivitas belajar secara tatap muka, tentunya akan membutuhkan orang lain yang bertindak sebagai pengajar, yaitu seorang guru yang dapat menyampaikan pengetahuan atau pengalaman yang dimilikinya kepada orang yang belajar (siswa) sehingga dimungkinkan tercipta proses belajar mengajar. Namun dalam proses belajar mengajar hendaknya menghindari situasi guru yang mendominasi kelas dan siswa menjadi pasif.

Pendekatan dan Jenis Penelitian Tindakan

1. Pendekatan Penelitian

Penelitian ini berusaha mendeskripsikan proses pembelajaran penjumlahan bilangan cacah berorientasi pada Pendekatan Pembelajaran StimulusRespon untuk meningkatkan pemahaman siswa terhadap konsep perkalian dan pembagian cepat pada bilangan cacah seperti apa adanya. Dalam penelitian ini, peneliti sebagai instrument utama, yaitu peneliti sebagai perencana dan pelaksana tindakan, pengamat, pewawancara dan pengumpul data. Untuk mengungkapkan proses pembelajaran ini, peneliti mengumpulkan data yang berupa kata-kata atau kalimat sehingga bersifat deskriptif. Data yang terkumpul ini kemudian dianalisis secara induktif. Disamping itu penelitian ini lebih menekankan proses pembelajaran penjumlahan bilangan cacah berorientasi pada Pendekatan Pembelajaran Stimulus-Respondari pada hasil pembelajaran. Proses yang diamati meliputi aktivitas siswa dan aktivitas guru selama proses pembelajaran berlangsung. Oleh karena itu pendekatan yang digunakan dalam penelitian ini adalah pendekatan kualitatif.

Sesuai dengan pendekatan penelitian yang akan digunakan yaitu pendekatan kualitatif dengan jenis penelitian tindakan partisipan, maka kehadiran peneliti di lapangan sangat diutamakan. Dalam hal ini peneliti bertindak sebagai instrumen utama dan pemberi tindakan pembelajaran dalam penelitian.

Peneliti sebagai instrumen utama adalah peneliti sebagai pewawancara dan pengamat. Sebagai pewawancara, peneliti akan mewawancarai subjek penelitian dengan berpedoman pada hasil pekerjaan siswa. Sebagai pengamat, yaitu mengamati aktivitas siswa selama berlangsungnya tindakan pembelajaran. Aktivitas siswa yang dimaksud berupa memanipulasi benda-benda konkret (butiran batu kerikil dan batangan sedotan), mengerjakan LKS, keaktifan bertanya. Peneliti sebagai pemberi tindakan pembelajaran maksudnya peneliti membuat rencana 
Maimunah: Nilai Positif....

pembelajaran dan menyajikan bahan ajar yang sesuai dengan tahapan pembelajaran Bruner. Selain itu, peneliti sebagai penganalisis data dan sekaligus pembuat laporan penelitian ini. Dalam pelaksanaan penelitian, peneliti akan dibantu oleh pengamat yaitu satu orang teman sejawat dan satu orang guru yang mengajarkan matematika. Lokasi penelitian adalah SDN 163086 Tebing Tinggi. Pemilihan lokasi penelitian didasarkan pada lokasi mengajar dan pertimbangan bahwa di sekolah tersebut terbuka untuk melakukan penelitian, dan guru bidang studi matematika setempat belum pernah menerapkan kegiatan pembelajaran yang berorientasi pada teori Stimulus-Respon.

Data yang dibutuhkan dalam penelitian ini adalah sebagai berikut.

1. Skor siswa terhadap soal-soal yang diberikan peneliti, meliputi tes awal sebelum tindakan, tes pada setiap akhir pembelajaran, dan tes akhir semua tindakan.

2. Wawancara dengan subjek penelitian berupa hasil rekaman tape recorder.

3. Lembaran hasil pengamatan selama pembelajaran berlangsung.

4. Lembaran hasil catatan lapangan tentang kegiatan penelitian dan kegiatan siswa selama dilakukan kegiatan pembelajaran yang berkaitan dengan tindakan.

Sumber data dalam penelitian ini adalah siswa VI SD Negeri 163086 Tebing Tinggi Tahun Pelajaran 2016/2017. yang ditentukan sebagai subjek penelitian. Penentuan siswa Kelas VI sebagai subjek penelitian tersebut agar fokus penelitian dapat diamati lebih cermat dan mendalam. Ketiga siswa tersebut dipilih berdasarkan hasil tes awal, yaitu siswa yang paling banyak melakukan kesalahan dalam menyelesaikan soal pada tes awal. Selain ditentukan oleh hasil tes awal, peneliti juga meminta pertimbangan dari guru matematika, karena guru lebih mengetahui keadaan siswa sehari-hari

Tahap-tahap Penelitian

Penelitian ini adalah penelitian tindakan yang tahap-tahapnya mengikuti tahap penelitian yang diuraikan oleh Kemmis (dalam Madya, 1994: 25) yang meliputi kegiatan perencanaan, pelaksanaan tindakan, observasi dan refleksi awal sebagai dasar untuk menentukan subyek penelitian. Secara operasional tahap-tahap penelitian adalah sebagai berikut.

1. Refleksi awal

Tahap awal dimulai dengan studi pendahuluan untuk menentukan subyek penelitian. Kegiatan yang dilakukan adalah memberikan tes awal untuk menentukan subyek penelitian.dan pemahaman mereka tentang konsep penjumlahan bilangan cacah.

Berdasarkan hasil tes awal tersebut dilakukan wawancara terhadap siswa yang terpilih sebagai subjek penelitian untuk mengetahui penyebab kesalahan yang dilakukannya.

2. Rencana Tindakan

Pada tahap ini dilakukan beberapa kegiatan, yaitu: (1) menyusun rencana pembelajaran konsep penjumlahan sebagai penjumlahan berulang, konsep pertukaran tempat terhadap penjumlahan. Masingmasing pembelajaran memuat tiga tahapan penyajian yaitu enaktif, ikonik dan simbolik, (2) menyiapkan bahan/alat peraga yang diperlukan, menyiapkan LKS, dan (3) menyiapkan lembar observasi yang 
akan digunakan oleh pengamat pada saat pelaksanaan tindakan.

\section{Pelaksanaan Tindakan}

Pelaksanaan tindakan direncanakan dua tahap yaitu pertama pembelajaran konsep penjumlahan sebagai penjumlahan berulang, kedua pembelajaran konsep pertukaran tempat terhadap penjumlahan. Tindakan dilaksanakan terhadap 3 siswa yang menjadi subyek penelitian, dengan menerapkan pembelajaran yang telah disusun pada tahap rencana tindakan. Pelaksanaan tindakan pembelajaran dilakukan oleh peneliti dibantu oleh satu orang guru kelas XI. Tindakan berakhir setelah siswa yang menjadi subjek penelitian dapat memahami penjumlahan bilangan cacah. Siswa dianggap telah memahami penjumlahan bilangan cacah jika telah mencapai skor lebih dari atau sama dengan 80 .

\section{Observasi dan Refleksi}

Kegiatan pada observasi ini adalah mengamati aktivitas siswa antara lain dalam memanipulasi alat peraga, bertanya, mengerjakan LKS, dan tugas-tugas yang diberikan oleh guru. Sedangkan aktivitas guru yang perlu diamati antara lain dalam merespon pendapat siswa, membimbing siswa yang mengalami kesulitan dalam mengerjakan LKS dan mengecek hasil pekerjaan siswa. Kegiatan observasi dilakukan selama pembelajaran berlangsung dengan menggunakan lembar observasi yang telah disiapkan oleh peneliti. Observasi dilakukan oleh peneliti dan dibantu oleh satu orang teman sejawat dan satu orang guru bidang studi. Tugas pengamat ini adalah sama dan apabila ada hal-hal yang tidak terjaring pada lembar observasi yang menurut pengamat merupakan hal yang penting, maka akan dilakukan pencatatan data. Disamping itu ada kegiatan refleksif yakni menganalisis, memahami, menjelaskan, menyimpulkan hasil pengamatan. Kegiatan ini sebagai upaya untuk memahami dan memaknai proses dan hasil yang dicapai sebagai akibat dari tindakan yang dilakukan. Hasil yang diperoleh pada kegiatan refleksi ini merupakan informasi (data) tentang apa yang telah terjadi dan apa yang perlu dilakukan selanjutnya. Data tersebut dikaji dan dipertimbangkan kembali apakah pemberian tindakan masih perlu diulangi atau sudah selesai. Jika masih perlu diulangi, maka peneliti menyusun kembali rencana tindakan (revisi) atau siklus berikutnya. Demikian seterusnya hingga penelitian berakhir.

\section{Siklus I}

Tindakan I pada penelitian ini merupakan upaya untuk meningkatkan pemahaman konsep perkalian cepat bilangan cacah khusus untuk perkalian dan pembagian secara cepat dan tepat untuk bilangan cacah sebagai perkalian berulang pada siswa Kelas VI SD Negeri 163086 Tebing Tinggi Tahun Pelajaran 2016/2017. Pembelajaran disusun dengan tujuan agar siswa dapat (1) menentukan bentuk perkalian cepat , (2) menentukan bentuk perkalian cepat, (3) menentukan hubungan perkalian cepat sebagai perkalian cepat berulang (hasil).

Pelaksanaan tindakan direncanakan 2 x 30 menit dialokasikan untuk 3 kegiatan. Kegiatan pertama berupa kegiatan awal 5 menit. Pada pelaksanaan tindakan dilakukan pengamatan oleh satu orang guru yang mengajar Matematika di Kelas VI SD Negeri 163086 Tebing Tinggi Tahun Pelajaran 2016/2017. Dan satu 
orang teman sejawat. Pengamat menggunakan lembar observasi dan melakukan catatan lapangan jika ada halhal yang tidak tercantum pada lembar observasi.

Siklus II

Siklus II pada penelitian ini merupakan upaya untuk meningkatkan pemahaman konsep perkalian cepat bilangan cacah khusus untuk perkalian cepat sebagai perkalian cepat berulang pada siswa Kelas VI SD Negeri 163086 Tebing Tinggi Tahun Pelajaran 2016/2017. Pembelajaran disusun dengan tujuan agar siswa dapat (1) menentukan bentuk perkalian cepat , (2) menentukan bentuk perkalian cepat , dan (3) menentukan hubungan perkalian cepat sebagai perkalian cepat berulang (hasil).

Pelaksanaan tindakan direncanakan 2 x 30 menit dialokasikan untuk tiga kegiatan. Kegiatan pertama berupa kegiatan awal $\square$ 5 menit. Pada kegiatan ini guru menyampaikan materi yang akan dibahas dan tujuan yang akan dicapai, selain itu dilakukan pula tanya jawab sehubungan dengan materi prasyarat untuk pembelajaran konsep perkalian cepat sebagai perkalian cepat berulang. Kegiatan kedua kegiatan inti $\square 40$ menit. Pada kegiatan ini guru melakukan pembelajaran dengan 3 tahap penyajian, yaitu enaktif, ikonik dan simbolik. Penyajian tahap enaktif menggunakan alat peraga berupa butiran batu kerikil dan batangan sedotan. Penyajian tahap ikonik menggunakan gambar-gambar dari alatalat peraga tersebut yang digambar langsung oleh siswa pada Lembar Kerja Siswa (LKS II). Kegiatan ketiga adalah kegiatan akhir 15 menit. Pada kegiatan ini guru melakukan tes formatif II dengan beberapa soal untuk dikerjakan oleh siswa. Rencana pembelajaran untuk tindakan ini sama saja dengan rencana pembelajaran I dengan LKS yang diberi nama LKS II.

Pada pelaksanaan tindakan dilakukan pengamatan oleh guru yang mengajar matematika di Kelas VI SD Negeri 163086 Tebing Tinggi Tahun Pelajaran 2016/2017. dan teman sejawat. Pengamat menggunakan lembar observasi dan melakukan catatan lapangan jika ada halhal yang tidak tercantum pada lembar observasi.

Hasil observasi yang diperoleh selama pembelajaran siklus I adalah sebagai berikut.

a. Pada awal pembelajaran guru memotivasi siswa dengan mengkomunikasikan tujuan pembelajaran yang akan dicapai, sehingga siswa antusias belajar untuk mencapai tujuan tersebut.

b. Guru menggali pengetahuan prasyarat yang dimiliki siswa sesuai dengan topik yang akan dibahas, dan ternyata materi prasyarat sudah dipahami oleh siswa sehingga tidak harus dijelaskan lagi oleh guru.

c. Alokasi waktu yang direncanakan untuk menyajikan pembelajaran I hanya satu kali pertemuan tapi penggunaan waktu lebih 15 menit dari yang direncanakan.

d. Guru membagikan alat peraga dan menjelaskan tujuan serta penggunaan masing-masing alat peraga tersebut.

e. Siswa kelihatan cukup aktif dalam memanipulasi alat peraga yang dibagikan, untuk menemukan konsep perkalian cepat sebagai perkalian cepat berulang dengan tujuan yang akan dicapai.

f. Siswa tidak diberikan petunjuk khusus untuk menemukan konsep 
perkalian cepat sebagai perkalian cepat berulang, sehingga pada aktivitas awal dalam menentukan perkalian cepat sebagai perkalian cepat berulang ada satu siswa yang melakukan kesalahan.

g. Pada saat siswa melakukan aktivitas untuk menentukan perkalian cepat sebagai perkalian cepat berulang dengan menggunakan butiran batu kerikil maupun dengan gambar, guru selalu mengamati. Apabila ditemukan siswa yang melakukan kesalahan, maka guru

Hasil Observasi dan Refleksi

Siklus II. Hasil observasi yang diperoleh selama pembelajaran II adalah sebagai berikut.

a. Pada awal pembelajaran guru memotivasi siswa dengan mengkomunikasikan tujuan pembelajaran yang akan dicapai, sehingga siswa termotivasi belajar untuk mencapai tujuan tersebut.

b. Siswa telah memiliki pengetahuan awal untuk mempelajari konsep pertukaran tempat terhadap perkalian cepat , sehingga dalam melakukan aktivitas untuk memahami konsep tersebut tidak terlalu mengalami kesulitan.

c. Guru membagikan alat peraga dan menjelaskan tujuan serta penggunaan masing-masing alat peraga tersebut.

d. Siswa kelihatan cukup aktif dan senang dalam memanipulasi alat peraga untuk menemukan konsep pertukaran tempat terhadap perkalian cepat , mereka menata sesuai dengan keinginan masingmasing sehingga mereka mandapatkan bentuk perkalian cepat yang berbedabeda.

Berdasarkan tanya-jawab yang dilakukan pada tahap awal, ditemukan bahwa ternyata semua siswa telah memahami materi perkalian cepat sebagai materi prasyarat untuk memahami konsep perkalian cepat sebagai perkalian cepat berulang. Materi prasyarat sebagai pengetahuan awal yang telah dimilik oleh siswa dapat mempengaruhi keberhasilan dalam pembelajaran selanjutnya. Hal ini sesuai dengan pendapat Bendal dan Galili (1993:169) yang menyatakan bahwa bila guru tidak memperhatikan pengetahuan awal siswa, maka akan mengalami kesulitan dalam mengikuti pembelajaran selanjutnya. Hal itu sesuai dengan pendapat Hudojo (1998:4) mengatakan konsep B akan sulit dipahami siswa jika tidak menguasai konsep A, karena konsep A adalah dasar bagi konsep B, karena adanya sifat hirarki yang dimiliki konsep matematika, yaitu konsepnya berkaitan dengan konsep-konsep yang lain.

Kegiatan dilanjutkan pada kegiatan inti. Pertama-tama yang dilakukan pada kegiatan inti pembelajaran siklus I adalah dengan penyajian tahap enaktif yaitu menggunakan alat peraga yang telah dibagikan. Kaitan materi yang akan dipelajari dan penggunaan alat peraga masih kurang dipahami oleh siswa. Hal itu menyebabkan guru memberikan penjelasan seperlunya tentang penggunaan alat peraga tersebut dan kaitannya dengan materi perkalian cepat . Suatu alat peraga tidak berarti apa-apa jika tidak dikaitkankan dengan materi matematika yang akan dipelajari (Ruseffendi, dkk, 1994 :230).

Pada penyajian tahap enaktif siswa Maimunah: Nilai Positif .. remahami konsep perkalian cepat sebagai perkalian cepat berulang dengan cara menata butiran batu kerikil dan batangan sedotan dengan jumlah yang sama sesuai dengan 
keinginan masing-masing. Sehingga dengan demikian konsep perkalian cepat sebagai perkalian cepat berulang tersebut dapat ditemukan sendiri oleh siswa. Kegiatan ini sesuai dengan teorema konstruksi yang dikemukakan oleh Bruner (dalam Ruseffendi, 1992 :110) bahwa untuk melekatkan ide atau defenisi tertentu dalam pikiran siswa, maka siswa harus menguasai konsep dengan melakukan sendiri penyusunan representasi konsep itu dengan bantuan benda konkret. Oleh sebab itu siswa akan lebih mudah mengingat ideide yang telah dipelajarinya tersebut. Pembelajaran pada siklus I belum berhasil, hal ini terlihat dari hasil tes formatif I masih ada siswa yang belum menjawab secara tepat semua soal yang diberikan khususnya pada bentuk perkalian cepat nya. Maka pembelajaran dilanjutkan pada tindakan I dengan pembelajaran yang sama tapi penekanan pada bentuk perkalian cepat nya. Setelah melakukan aktivitas yang sama pada siklus I sampai dengan tes formatif II ternyata hasilnya dapat dinyatakan bahwa siswa sudah berhasil.

Penggunaan waktu yang lebih lama dengan hasil belajar yang lebih baik itu sesuai dengan hasil penelitian yang dilakukan oleh Saki (2002: 74) bahwa alokasi waktu yang direncanakan hanya satu kali pertemuan, ternyata dalam pelaksanaan tindakan menjadi tiga kali pertemuan tetapi pembelajaran berorientasi pada Pendekatan Pembelajaran Stimulus-Respondapat meningkatkan pemahaman perkalian cepat pada siswa Kelas VI SD Negeri 163086 Tebing Tinggi Tahun Pelajaran 2016/2017. Demikian halnya pada penelitian ini, alokasi waktu yang digunakan selama pembelajaran I dan pembelajaran II selalu lebih antara 10-15 menit dari waktu yang telah direncanakan. Hal ini disebabkan ketika siswa memanipulasi benda-benda konkret dan pengisian LKS cenderung menggunakan waktu yang agak lama. Sesuai pendapat Dahar (1988:126) bahwa belajar dengan penerapan Pendekatan Pembelajaran Stimulus-Responmembutuhkan waktu yang lama.

Hasil skor yang diperoleh siswa ketika diadakan tes formatif rata-rata $\square 80$. artinya penelitian ini membenarkan bahwa belajar dengan penemuan (berorientasi pada teori Stimulus-Respon) menunjukkan beberapa kelebihan, yaitu: (1) pengetahuan dapat bertahan lama, (2) kemampuan penalaran siswa meningkat, (3) dapat membangkaitkan motivasi siswa Kelas VI SD Negeri 163086 Tebing Tinggi Tahun Pelajaran 2016/2017.

Kesimpulan

Dari paparan data dan temuan penelitian yang telah diuraikan dalam Bab IV pembahasan, maka kesimpulan yang dapat diambil dari penelitian ini adalah sebagai berikut.

1. Bentuk pembelajaran berorientasi pada Pendekatan Pembelajaran StimulusRespon yang dapat meningkatkan pemahaman siswa Kelas VI SD Negeri 163086 Tebing Tinggi Tahun Pelajaran 2016/2017 adalah suatu bentuk pembelajaran dengan penyajian tiga tahapan yaitu enaktif, ikonik dan simbolik.

2. Pembelajaran berorientasi pada Pendekatan Pembelajaran StimulusRespon sangat memotivasi siswa Kelas VI SD Negeri 163086 Tebing Tinggi Tahun Pelajaran 2016/2017 dalam belajar matematika, karena mereka merasa belajar 
Maimunah: Nilai Positif ..

sambil bermain dan tidak lai menimbulkan rasa takut untuk belajar matematika.

Berdasarkan temuan dan kesimpulan yang diperoleh dalam penelitian ini, diajukan saran-saran sebagai berikut.

1. Untuk menanamkan perkalian cepat pertukaran tempat terhadap operasi hitung bilangan cacah bagi siswa Kelas VI SD Negeri 163086 Tebing Tinggi Tahun Pelajaran 2016/2017 sebaiknya guru membuat rencana pembelajaran dan melaksanakan pembelajaran berorientasi pada teori Stimulus-Respon. Yaitu pembelajaran melalui 3 tahap penyajian yakni enaktif, ikonik dan simbolik. Pada setiap tahap penyajian perlu disusun langkah-langkah pembelajaran yang memungkinkan siswa untuk mendapatkan konsep yang dipelajarinya.

2. Guru perlu menyiapkan atau meminta siswa menyediakan benda-benda konkret yang ada disekitar siswa untuk digunakan secara langsung dalam memahami konsep perkalian cepat .

3. Selain bimbingan dan arahan dari guru, perlu pula memberikan kesempatan kepada siswa untuk menemukan sendiri konsep dari suatu materi yang dipelajari, agar belajarnya lebih bermakna.

\section{DAFTAR RUJUKAN}

Alipandie, I. 1984. Didaktik Pendidikan Umum. Surabaya: Usaha Nasional

Anam, Khoirul. 2000. Implementasi Cooperative Learning dalam Pembelajaran Geografi Adaptasi Model Jigsaw dan Field Study. Ruletin Pelanoi Pendidikan, e-ISSN 2355-1747

Arikunto, S. 2001. Manajemen Penelitian. Jakarta: Depdikbud

Arikunto, S. 2002. Prosedur Penelitian Suatu Pendekatan Praktek (Edisi Revisi IV). Jakarta: PT Rineka Cipta

Arikunto, S. 2001. Dasar-dasar Evaluasi Pendidikan (Edisi Revisi). Jakarta: Bina Aksara

As'ari, Abdur Rahman. 2002. Beberapa Hal Penting tentang Pembelajaran Matematika dengan Cooperatif Learning. Makalah disajikan dalam Simposium Guru Matematika keV, Yogyakarta, 11-14 Nopember.

Depdikbud. 2000. Materi Dasar Pendidikan Program Akta Mengajar V:Metodologi Penelitian. Jakarta:Depdikbud

Depdikbud. 2000. Kamus Besar Bahasa Indonesia. Jakarta: Depdikbud

Hudoyo, Herman. 2003. Pengembangan Kurikulum Matematika dan Pelaksanaannya di Kelas. Surabaya: Usaha Nasional

Isparjadi. 2003. Statistik Pendidikan. Jakarta: Depdikbud 
